https://doi.org/10.48009/2_iis_2010_66-71

\title{
INTRODUCING BUSINESS METHOD PATENTS INTO THE IS CURRICULUM
}

\author{
Nancy L. Martin, Southern Illinois University, nlmartin@ siu.edu
}

\begin{abstract}
Business method patents are a viable strategic weapon when used to protect intellectual property. At the same time, studies have shown that coverage of intellectual property in the IS curriculum is lacking. This paper suggests the use of a research assignment in IS courses that can help students understand the use of patents as a competitive strategy. Background material is provided for instructors, along with suggestions for assignment design and patent research resources.
\end{abstract}

Keywords: IS curriculum, intellectual property, competitive advantage

\section{INTRODUCTION}

The United States Patent and Trademark Office (USPTO) has been awarding patents on computer software for nearly 30 years. While software by definition is protected by copyright, ideas or new ways of doing business, which are sometimes embedded in software and require a machine to implement, are patentable. This category of patents is generally known as business method patents, but more often referred to simply as software patents.

Business method patents have been a popular topic in business trade press for many years. Patents such as Amazon.com's one-click ordering patent and Priceline.com's reverse auction patent are well known in information systems circles. Yet, information systems curriculums in general do not address the phenomenon, or other intellectual property issues adequately [25].

Most of these curriculums do, however, include an introductory course designed to expose students to a variety of information systems topics, the most relevant to this paper being competitive strategy. This paper suggests incorporating business method patents, a form of intellectual property, into a research assignment related to competitive strategy in the introductory course or other strategy related information systems courses.

Volume XI, No. 2, 2010
First, the background and current issues surrounding business method patents are outlined as a reference for instructors. Then, a short summary of the suggested research assignments that will allow students and faculty to better understand the strategy of business method patenting is offered. Resources for research are also included.

\section{BACKGROUND}

Intellectual property is an important asset in the current knowledge-based economy. Intellectual property generally includes knowledge-based intangible assets, some of which may be protected through patents, trademarks, copyrights, or trade secrets. In recent years, many organizations have chosen to protect one type of intellectual property, software-based business methods, through the U.S. patent system. The use of patents to protect softwarebased business methods is a topic of particular interest in the current business press primarily due to the enormous growth in applications and the number of these patents issued in the U.S. during the last decade, the resulting explosion in patent litigation, and recent definition changes due to court rulings.

For more than two centuries, the U.S. government has used the patent system to reward inventors for their innovations. The USPTO issues patents which confer the legal right to exclude others from making, using, or selling the patented invention for twenty years. If another party infringes upon the patent, the owner may sue to recover lost profits and possibly additional monetary damages.

Patent law states that patents can only be granted for inventions that are useful, new, and non-obvious. The useful requirement is fairly intuitive. The new requirement means that the innovation must represent an advance over existing knowledge, which patent lawyers term prior art. Non-obviousness is somewhat less clear. This requirement prevents the patenting of an invention that would have been obvious to a practitioner in the relevant field at the time the invention was created.

The legal patent document contains detailed information about the invention, the inventor, assignee, and the technological antecedents of the

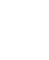


invention, including citations to previous patents. Claims are the parts of a patent that define the legal boundaries of patent protection. Each claim should have only one meaning which can be either broad or narrow constituting the scope of the claim. A patent with many claims, each differing in scope, permits legal title to several aspects of the invention.

Citations serve an important legal function since they help delimit the scope of the property rights awarded by the patent. The applicant has a legal obligation to disclose any knowledge of the prior art, but the decision regarding which citations to include in the patent document ultimately rests with the patent examiner who should be an expert in the area and therefore able to thoroughly identify prior art.

Although the patent system has been around for more than 200 years, software and business method patenting are relatively recent phenomena. The USPTO traditionally was reluctant to grant patents on computer software inventions. Throughout the 1970s, the USPTO resisted granting such patents on the basis that computer programs were classified as mathematical algorithms and thus did not fall into the patentable categories of processes, machines, articles of manufacture or compositions of matter. Rather, policymakers during the 1970s preferred the copyright as the preferred means for protecting software-related intellectual property, and the Copyright Act of 1980 was amended to allow such protection.

However, several important court decisions eventually narrowed the protection provided by copyright. Lotus Development had successfully sued both Paperback Software International and Borland International over alleged imitation of its spreadsheet software. The Borland decision was eventually reversed on the basis that "second movers" in the software industry must be allowed to emulate and build on parts of the innovator's code and methods [18]. This decision, along with others, weakened the strong protection copyrights had afforded software inventions and is believed to have contributed to the increased reliance on software patents.

In contrast to the narrowing of copyright protection, court decisions and, to some extent, the USPTO itself, dramatically broadened and strengthened the use of software patents over the past three decades. A Supreme Court decision in 1981 ushered in changes in software patentability. In Diamond $v$. Diehr [10], the court upheld the patentability of a computer program-controlled industrial process for curing rubber. Following that decision, a series of other court decisions gradually relaxed the restrictions for the patenting of software-related inventions.

Patents in general were strengthened through the administrative decision to create the United States Court of Appeals for the Federal Circuit (CAFC) in 1982. Prior to 1982, patent infringement cases of any type were rarely upheld. This was partly due to the fact that patent infringement cases were part of the regular docket in the U.S. Courts of Appeals and were therefore spread across many jurisdictions resulting in inconsistent handling. However, from its inception, the CAFC was responsible for appeals of district court decisions involving patent lawsuits and also for appeals of patent applications that were rejected by the USPTO. The CAFC is believed to be responsible for the significant increase in decisions supporting patent validity [2].

It is also widely believed that a 1998 CAFC decision in the case of State Street Bank \& Trust Co. v. Signature Financial Group, Inc. [33] was instrumental in highlighting the broadened scope of software patents which included software-based business methods [17]. Signature obtained a patent in 1993 on a software program that was used to determine the value of mutual funds. State Street Bank sued to have the patent invalidated on the grounds that it covered a business method and was hence not patentable. In the final appeal with the CAFC, the court explicitly rejected State Street's claim and Signature's patent was upheld. The decision specifically stated that software that governs business methods can be patented as long as it produces some concrete, useful, tangible result [26]. That decision marked the beginning of the enormous increase in software patent applications.

Business method patents as a definitive class are relatively new. The USPTO created patent class 705 specifically for business method inventions in 1997. Class 705 is a collection of more than 20 financial and management data processing areas including, but not limited to, insurance, stock/bond trading, health care management, reservation systems, computerized postage meter systems and more general enterprise functions such as electronic shopping, auction systems, and business cryptography [35]. Amazon.com's patent of the one-click ordering system is a well-known example of a software-based business method patent. Other familiar examples of business method patents include Priceline.com's patent for "name your price" reverse auctions and Doubleclick's patent for Internet advertising. 
Like any other patent, business method patents are not awarded without proving the invention's merit. In the past, patent law required that four tests be met for a business method to be patentable:

1. The way of doing business must be useful;

2. It has to be new. The USPTO does not issue patents for old business methods simply converted to electronic form;

3. It cannot be so incremental that it would be obvious to a skilled practitioner; and

4. In the application process, disclosure of the innovation has to be so complete that fellow practitioners can understand it.

After the State Street Bank case, the number of class 705 applications skyrocketed. At the end of 2009, more than 15,000 business method patents had been awarded. Many organizations, large and small, public and private, have been awarded business method patents as organizations seek patents to protect a variety of software-enabled business methods.

However, recent events may halt the ability for business methods, including software-based business methods, to be as easily patented in the future. A recent U.S. Federal Circuit Court ruling, In re Bilski [13], involved Bernard Bilski and Rand Warsaw, who founded the company WeatherWise to sell computerized services based on their hedging method that is used by some utilities. The USPTO rejected the WeatherWise patent application in 2000; the USPTO Patent Board of Appeals upheld the rejection in 2006, and the CAFC upheld the decision in 2008. The denial was based on the interpretation that the claim involved a mental process, and did not require technology to implement.

There is uncertainty of the impact of the Bilski ruling on business method and software patents. Some view decisions made by the USPTO as leading to the invalidation of many software and business process patents [34]. The Bilski ruling did not explicitly overrule the State Street decision, but it did assert that the concrete, useful, tangible test alone is inadequate. The Bilski case was appealed to the U.S. Supreme Court. In late 2009 arguments were presented before the court, and a ruling will likely be issued in spring or summer 2010.
If the Bilski ruling is upheld by the U.S. Supreme Court, it does not mean that business method patents will be ineligible, but based on the Bilski ruling and comments from the Supreme Court, it appears it may be nearly impossible for most business methods to pass the machine-or-transformation test, the basic test for all patent eligibility. This test requires that the claimed method either be tied to a particular machine or apparatus, or that it transform a particular article into a different state or thing. The greatest risk to business method patents is that the USPTO Board of Patent Appeals has already declared that a generalpurpose computer is not considered a particular machine for the purposes of patent eligibility. Therefore, software processes alone are unpatentable. This issue is likely to arise in future court decisions.

The court rulings are important in that they may force significant change upon an organization's use of business method patents as part of its overall competitive strategy. A patent is a desired form of intellectual property in that it provides legal protection of an innovation to the patent owner for a period of 20 years. Although there has been strong debate over the logic of awarding patents to business methods or software, patents are used by some firms to obtain strategic advantages in negotiations, crosslicensing, blocking competitors, and preventing lawsuits [3]. Organizations also use business method patents as a defensive strategy or to show potential investors the legitimacy of an innovation [24]. Although it has been difficult to link business method patents directly to financial performance [19], some firms have enjoyed favorable stock price reactions when awarded a business method patent [5].

Other firms have acquired business method and other software-based patents, but have shifted their patent strategy by joining the patent commons movement [27]. In the spirit of the open source software movement, some patent holders have chosen to join the patent commons by publicly posting a document that makes a commitment to not legally enforce the patents they hold. Some of the companies that have made the commitment to not enforce at least some of their patents include IBM, Microsoft, Sun Microsystems, Oracle, HP, and Blackboard.

Although In re Bilski dealt a blow to business method patents, it did not eliminate them completely. Without clear guidelines, the burden of support is on the patent applicant. For now, organizations must reassess their reliance on the business method patent as part of their competitive strategy. 


\section{PATENTS IN THE IS CURRICULUM}

In most information systems curriculums, an introductory course in management information systems (MIS) is offered. The 2002 and draft 2010 IS Model Curriculum [14] suggest such a course and an additional course in information systems strategy, management and acquisition. Additionally, the 2008 IT Model Curriculum [15] specifically suggests coverage of intellectual property. It is within any of these courses that faculty have the opportunity to introduce the topic of intellectual property management, specifically software and business method patents.

Intellectual property coverage generally includes the use of copyrights, trademarks, patents and the legal and ethical issues surrounding them. Even though curriculum guides suggest coverage of intellectual property, one study found that information systems academia has done a less than desirable job of integrating those issues into undergraduate MIS degree programs [25], leaving graduates ill equipped in this area of knowledge.

\section{Competitive Advantage Theory}

In nearly every introductory MIS textbook, the topic of competitive advantage is covered. To support the notion that information technology (IT) can be used as a strategic weapon in gaining competitive advantage, early scholars provided numerous case studies of firms such as American Airlines [8, 11, 12] and American Hospital Supply Corporation [22, 32], as well as conceptual frameworks [1, 20, 21, 30] suggesting that IT can contribute to competitive advantage by creating easier access to markets, increasing product differentiation, improving cost efficiencies, or changing the nature of an industry.

Information systems competitive advantage research eventually advanced beyond conceptual development through the examination of numerous factors, capabilities and complementary resources that might influence a firm's ability to create and sustain competitive advantage with IT $[4,6,9,16,31]$. Reviews by Melville, Kraemer, and Gurbaxani [23], Piccoli and Ives [28], and Wade and Hulland [36] provide comprehensive syntheses of this type of research. Although, some have hotly debated the strategic value of IT [7], today, scholars largely agree that it is not the IT itself, but rather the IT-dependent strategic initiative, that can be a source of competitive advantage [28].
Such strategic initiatives often involve the use of proprietary information and information systems, and as such are discussed in introductory MIS courses. In most introductory texts, competitive advantage theory is introduced using Porter's Five Forces Model [29]. This timeless model suggests that organizations' position and strategies are impacted not only by their direct competitors, but also by the forces of suppliers, customers, new market entrants, and the potential for substitute products or services. To combat these forces, organizations might choose one or more of several strategies such as becoming the low cost producer, strengthening customer and/or intimacy, focusing on niche markets, or creating unique products or services.

\section{Research Assignment}

While there exists a number of possible assignments or projects to engage students' understanding of competitive strategy, a research assignment related to the acquisition and use of business method patents provides an interesting spin and gives the students an opportunity to analyze an organization's competitive strategy related to intellectual property.

There are organizations whose entire business model was built upon their patent such as Priceline.com. But there are also numerous other business method patents that were obtained for other strategic purposes, such as Disney's Fast Pass system for accessing park rides. The primary task for the students' is to research the use of business method or software patents within the framework of competitive strategy theory.

The assignment may be used as an individual or group project and might take one of two approaches as commonly found in introductory MIS courses: indepth or wide-breadth [37]. In the wide-breadth assignment, students are encouraged to identify a business method or software patent that address a competitive reaction to each of Porter's Five Forces. In this case, the students report on at least five patents and how they are utilized by the assignees to respond to particular threats. This information can be found by researching company websites, traditional library databases such as Lexis/Nexis or EBSCO, and/or annual reports filed by publicly held companies. Trade magazines such as Information Week often report on uses of patents as well. Additionally, an internet search will produce a number of websites that provide timely coverage of business method patent topics. This type of assignment would be 
considered an introductory level and would be appropriate for lower level undergraduate students.

In an in-depth research assignment or case study, students identify one business method or software patent and provide an analysis of the use of the patent, relevant organizational background, additional patents that have been created based on the original, and possibly any litigation that has resulted due to alleged infringement. In this type of project, students follow the patent, not necessarily the company. For example, many original class 705 patents were assigned to companies that were eventually purchased for the patented technology. A classic example is Doubleclick which owns the patent for banner advertising, but the company was subsequently acquired by Google. This type of project would be appropriate for upper level undergraduate or graduate students.

Another option for an in-depth project is to ask the students to evaluate one or more business method patents based on the In re Bilski definition, the machine or transformation test. This will allow the students to discuss whether or not the patent might become invalidated and what that could mean to the organization in terms of strategic response. The students would offer strategic plans or other approaches for the organization to protect or attain competitive advantage in the event of an invalidated patent. This assignment would also be appropriate for upper level or graduate students.

In all of the suggested assignments, the learning outcome is that students gain a better understanding of how some organizations use intellectual property to address competitive threats. Students should be encouraged to clearly identify their perceived strategic purpose for the organizations to obtain patents such as cross-licensing, defensive positioning, or other reasons discussed earlier.

\section{Patent Resources}

The USPTO website is a treasure trove of data. There, students can search for patents by a particular class, e.g. class 705 , by assignee, by keyword, or a number of other indicators. Users of the site can view the patent document in its entirety. To help students isolate potential patents, it is recommended that they focus on patent class 705 . Some students may also identify known patents they wish to research such as Amazon.com's one-click ordering patent rather than searching for an appropriate but unknown patent.
In addition to actual patent documents, the USPTO website offers access to a variety of statistics and reports such as number of patents issued by class and the top patenting organizations by class and by year. Google.com also offers a patent search tool that utilizes its own patented page rank algorithm to better filter results (www.google.com/patents). Students should be encouraged to try both tools.

\section{CONCLUSION}

Business method patents are a popular and controversial form of intellectual property that has attracted attention from organizations, in the courts, and in the press in recent years. A patent is designed to confer legal protection of an innovation to the patent owner for a period of 20 years. With today's rapid pace of technological change, it is not likely that a competitive advantage will last for 20 years. However, patent protection may invoke some period of protection from imitation that would not have otherwise been afforded. This discussion suggests that it is important to consider the role of these patents in a modern information systems curriculum.

This paper has offered instructors a consolidation of background material including the history and current issues related to business method patents, and the rationale to support integration of this important topic into introductory MIS courses or other strategyrelated courses. A variety of research assignments have been presented with options for both in-depth and wide-depth approaches and for various levels of difficulty and students.

Incorporating this timely topic into the information systems curriculum will increase students' understanding about how information systems can contribute to competitive advantage and the value of intellectual property.

\section{REFERENCES}

1. Bakos, J. Y., \& Treacy, M. E. (1986). Information technology and corporate strategy: A research perspective. MIS Quarterly, 10(2), 107-119.

2. Bender, D., \& Barkume, A. R. (1992). Patents for software-related inventions. Software Law Journal, 5, 279-298.

3. Bessen, J., \& Hunt, R. M. (2007). An empirical look at software patents. Journal of Economics and Management Strategy, 16(1), 157-189.

4. Bharadwaj, A. (2000). A resource-based perspective on information technology capability 
and firm performance: An empirical investigation. MIS Quarterly, 24(1), 169-196.

5. Boscaljon, B., Filbeck, G., \& Smaby, T. (2006). Information content of business methods patents. Financial Review, 41(3), 387-404.

6. Brown, R. M., Gatian, A. W., \& Hicks Jr., J. O. (1995). Strategic information systems and financial performance. Journal of Management Information Systems, 11(4), 215-248.

7. Carr, N. G. (2003). IT doesn't matter. Harvard Business Review, 81(5), 41-49.

8. Copeland, D. G., \& McKenney, J. L. (1988). Airline reservation systems: Lessons from history. MIS Quarterly, 12(3), 353-370.

9. Dehning, B., \& Stratopoulos, T. (2003). Determinants of a sustainable competitive advantage due to an IT-enabled strategy. Journal of Strategic Information Systems, 12(1), 7-28.

10. Diamond v. Diehr, 450 U.S. 175 (1981).

11. Doll, W. J. (1989). Information technology's strategic impact on the American air travel service industry. Information \& Management, 16(5), 269-275.

12. Hopper, M. D. (1990). Rattling SABRE--New ways to compete on information. Harvard Business Review, 68(3), 118.

13. In re Bilski, 545 F.3d 943, 88 U.S.P.Q.2d 1385 (2008).

14. IS2002. (2002). Curriculum guidelines for undergraduate degree programs in information systems.

15. IT2008. (2008). Curriculum guidelines for undergraduate degree programs in information technology.

16. Kettinger, W. J., Grover, V., Guha, S., \& Segars, A. H. (1994). Strategic information systems revisited: A study in sustainability and performance. MIS Quarterly, 18(1), 31-58.

17. Lesavich, S. (2001). Are all business method patents "one-click" away from vulnerability? Intellectual Property \& Technology Law Journal, 13(6), 1-5.

18. Lotus Development Corporation v. Borland International, Inc., 831 F. Supp. 223 (D. Mass.1993).

19. Martin, N. L., \& Mykytyn, J., Peter P. (2009). Evaluating the financial performance of business method patent owners. Information Systems Management, 26(3), 285-301.

20. Mata, F. J., Fuerst, W. L., \& Barney, J. (1995). Information technology and sustained competitive advantage: A resource-based analysis. MIS Quarterly, 19(4), 487-505.

21. McFarlan, F. W. (1984). Information technology changes the way you compete. Harvard Business Review, 62(3), 98-103.
22. McKenney, J. L. (1995). Waves of change: Business evolution through information technology. Boston: Harvard Business School Press.

23. Melville, N., Kraemer, K., \& Gurbaxani, V. (2004). Review: Information technology and organizational performance: An integrative model of IT business value. MIS Quarterly, 28(2), 283-322.

24. Meyer, S. P. (1992). Obtaining and enforcing patents for software-related inventions: Avoiding the pitfalls. Software Law Journal, 5, 715-738.

25. Mykytyn, P. P., Mykytyn, K., \& Harrison, D. A. (2005). Integrating intellectual property concepts into MIS education: An empirical assessment. Decision Sciences Journal of Innovative Education, 3(1), 1-27.

26. Ovans, A. (2000). Can you patent your business model? Harvard Business Review, 78, 16.

27. Patent

Commons. http://www.patentcommons.org

28. Piccoli, G., \& Ives, B. (2005). Review: ITdependent strategic initiatives and sustained competitive advantage: A review and synthesis of the literature. MIS Quarterly, 29(4), 747-776.

29. Porter, M. (1980). Competitive strategy. New York: Free Press.

30. Porter, M. E., \& Millar, V. E. (1985). How information gives you competitive advantage. Harvard Business Review, 63(4), 149-160.

31. Santhanam, R., \& Hartono, E. (2003). Issues in linking information technology capability to firm performance. MIS Quarterly, 27(1), 125-153.

32. Short, J. E., \& Venkatraman, N. (1992). Beyond business process redesign: Redefining Baxter's business network. Sloan Management Review, 34(1), 7-21.

33. State Street Bank \& Trust Company v. Signature Financial Group, Inc., 149 f.2d 1368 (CAFC 1998).

34. Turner, J. (2009, March 13). Has the U.S. patent system gone too far? Christian Science Monitor, pp. 25.

35. U.S. Patent and Trademark Office. (2000). Class 705 classification definitions. Retrieved February 22, 2006, from http://www.uspto.gov/web/offices/ac/ido/oeip/taf $/ \mathrm{def} / 705 . \mathrm{htm}$

36. Wade, M., \& Hulland, J. (2004). The resourcebased view and information systems research: Review, extension and suggestions for future research. MIS Quarterly, 28(1), 107-142.

37. Wang, S. (2007). An examination of the introductory MIS course. Journal of Information Technology Education, 6, 135-152. 